\title{
Editorial
}

\section{Coastal Fish Research}

\author{
Francesco Tiralongo (D)
}

Citation: Tiralongo, F. Coastal Fish Research. J. Mar. Sci. Eng. 2021, 9, 546. https://doi.org/10.3390/jmse905 0546

Received: 12 May 2021

Accepted: 17 May 2021

Published: 18 May 2021

Publisher's Note: MDPI stays neutral with regard to jurisdictional claims in published maps and institutional affiliations.

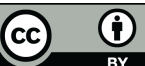

Copyright: (c) 2021 by the author. Licensee MDPI, Basel, Switzerland. This article is an open access article distributed under the terms and conditions of the Creative Commons Attribution (CC BY) license (https:/ / creativecommons.org/licenses/by/ $4.0 /)$.
Department of Biological, Geological and Environmental Sciences, University of Catania, 95124 Catania, Italy; francesco.tiralongo@unict.it

Coastal fish are key components of marine ecosystems, influencing, directly or indirectly, marine life worldwide. Furthermore, among coastal fish, there are many species that represent target species for many fisheries (commercial and recreational) and contribute considerably to the economy of several coastal countries. Despite this, the biology and ecology of several species still remain little known or unknown, with several species waiting to be described. Furthermore, many fish stocks are being overexploited and in urgent need of sustainable management. Another interesting side of coastal fish is their importance as bioindicators of the status of the aquatic ecosystems. Indeed, often, coastal fish are directly exposed (and sometimes seriously threatened) to a variety of human impacts (e.g., pollution, habitat destruction, overfishing) [1]. On the other hand, invasive alien coastal fish represent in many areas a serious threat to marine biodiversity and in some cases to economy and human health.

It thus appears clear that understanding and deepening knowledge around biology and ecology of coastal fish is one of the main challenges for marine biologists and ecologists. For example, in an era in which invasive alien species threaten marine biodiversity, but can also have economic and human health impacts, the understanding of the dynamics and processes underlying biological invasions is of fundamental importance for effective management and conservation of biodiversity and ecological integrity [2]. Furthermore, the increasing marine pollution represents a serious threat to coastal fish and to marine life in general, although this phenomenon encompasses a great variety of aspects and effects on marine fish are often difficult to detect and quantify. However, some types of laboratory analysis on coastal fish fauna can give good indications of the general status of the marine environment and of the effects that specific pollutants can have on fish populations.

This special edition is intended to be a contribution to the knowledge of several aspects of fish biology and ecology: coastal fish diversity, coastal fisheries and commercial species, biological invasions process and non-indigenous species, interactions between fish and their environment, ethology, bioaccumulation and reproduction [1-12]. I hope this special issue will be helpful for all marine biologists involved in studies on fish biology and ecology.

Funding: This research received no external funding.

Conflicts of Interest: The author declares no conflict of interest. 


\section{References}

1. Salvaggio, A.; Pecoraro, R.; Copat, C.; Ferrante, M.; Grasso, A.; Scalisi, E.M.; Ignoto, S.; Bonaccorsi, V.S.; Messina, G.; Lombardo, B.M.; et al. Bioaccumulation of Metals/Metalloids and Histological and Immunohistochemical Changes in the Tissue of the European Hake, Merluccius merluccius (Linnaeus, 1758) (Pisces: Gadiformes: Merlucciidae), for Environmental Pollution Assessment. J. Mar. Sci. Eng. 2020, 8, 712. [CrossRef]

2. Tiralongo, F.; Messina, G.; Lombardo, B. Invasive Species Control: Predation on the Alien Crab Percnon gibbesi (H. Milne Edwards, 1853) (Malacostraca: Percnidae) by the Rock Goby, Gobius paganellus Linnaeus, 1758 (Actinopterygii: Gobiidae). J. Mar. Sci. Eng. 2021, 9, 393. [CrossRef]

3. Macali, A.; Semenov, A.; De Mendoza, F.P.; Dinoi, A.; Bergami, E.; Tiralongo, F. Relative Influence of Environmental Factors on Biodiversity and Behavioural Traits of a Rare Mesopelagic Fish, Trachipterus trachypterus (Gmelin, 1789), in a Continental Shelf Front of the Mediterranean Sea. J. Mar. Sci. Eng. 2020, 8, 581. [CrossRef]

4. Tiralongo, F.; Messina, G.; Lombardo, B.M. Biological Aspects of Juveniles of the Common Stingray, Dasyatis pastinaca (Linnaeus, 1758) (Elasmobranchii, Dasyatidae), from the Central Mediterranean Sea. J. Mar. Sci. Eng. 2020, 8, 269. [CrossRef]

5. Candelma, M.; Marisaldi, L.; Bertotto, D.; Radaelli, G.; Gioacchini, G.; Santojanni, A.; Colella, S.; Carnevali, O. Aspects of Reproductive Biology of the European Hake (Merluccius merluccius) in the Northern and Central Adriatic Sea (GSA 17-Central Mediterranean Sea). J. Mar. Sci. Eng. 2021, 9, 389. [CrossRef]

6. $\quad$ Bruneel, S.; Van Echelpoel, W.; Ho, L.; Raat, H.; Schoeters, A.; De Troyer, N.; Sor, R.; Ponton-Cevallos, J.; Vandeputte, R.; Van der Heyden, C.; et al. Assessing the Drivers behind the Structure and Diversity of Fish Assemblages Associated with Rocky Shores in the Galapagos Archipelago. J. Mar. Sci. Eng. 2021, 9, 375. [CrossRef]

7. Di Blasi, D.; Canese, S.; Carlig, E.; Parker, S.; Pisano, E.; Vacchi, M.; Ghigliotti, L. The Challenge to Observe Antarctic Toothfish (Dissostichus mawsoni) under Fast Ice. J. Mar. Sci. Eng. 2021, 9, 255. [CrossRef]

8. Čekovská, K.; Šanda, R.; Eliášová, K.; Kovačić, M.; Zogaris, S.; Pappalardo, A.M.; Soukupová, T.; Vukić, J. Population Genetic Diversity of Two Marine Gobies (Gobiiformes: Gobiidae) from the North-Eastern Atlantic and the Mediterranean Sea. J. Mar. Sci. Eng. 2020, 8, 792. [CrossRef]

9. Lu, Y.; Yu, J.; Lin, Z.; Chen, P. Environmental Influence on the Spatiotemporal Variability of Spawning Grounds in the Western Guangdong Waters, South China Sea. J. Mar. Sci. Eng. 2020, 8, 607. [CrossRef]

10. Park, J.M.; Riedel, R.; Ju, H.H.; Choi, H.C. Fish Assemblage Structure Comparison between Freshwater and Estuarine Habitats in the Lower Nakdong River, South Korea. J. Mar. Sci. Eng. 2020, 8, 496. [CrossRef]

11. Spyridopoulou, R.N.A.; Langeneck, J.; Bouziotis, D.; Giovos, I.; Kleitou, P.; Kalogirou, S. Filling the Gap of Data-Limited Fish Species in the Eastern Mediterranean Sea: A Contribution by Citizen Science. J. Mar. Sci. Eng. 2020, 8, 107. [CrossRef]

12. Zhang, J.; Ren, C.; Zhang, H.; Yin, F.; Zhang, S.; Wan, R.; Kitazawa, D. Review of Estimating Trophic Relationships by Quantitative Fatty Acid Signature Analysis. J. Mar. Sci. Eng. 2020, 8, 1030. [CrossRef] 